\title{
REFLECTIONS ON THE DEEP CONNECTION BETWEEN PROBLEMS OF EVIL AND PROBLEMS OF DIVINE HIDDENNESS
}

\section{TRENT DOUGHERTY}

Baylor University

\begin{abstract}
In the literature on the subject, it is common to understand the problem of divine hiddenness and the problem of evil as distinct problems. Schellenberg $(1993,2010)$ and van Inwagen (2002) are representative. Such a sharp distinction is not so obvious to me. In this essay, I explore the relationship between the problem(s) of evil and the problem(s) of divine hiddenness.
\end{abstract}

\section{INTRODUCTION: PROBLEMS AND PUZZLES}

In the literature on the subject, it is common to understand the problem of divine hiddenness and the problem of evil as distinct problems. Schellenberg $(1993,2010)$ and van Inwagen $(2002)$ are representative. Such a sharp distinction is not so obvious to me. In this essay, I explore the relationship between the problem(s) of evil and the problem(s) of divine hiddenness. The lens through which I will view these two problems is a certain distinction between a problem and a puzzle. ${ }^{1}$ It behooves me therefore to say a few words about how I am thinking about this distinction for the purposes of this meditation. In broad terms, I will be exploring dependency relationships between the two purportedly separate issues. I will not do very much with my conclusions here. Rather, I am exploring a path for further research. I will only sketch the outlines of one possible application. I will be invoking a "move" (for lack of a better word) mentioned by William Rowe very early in the

${ }^{1}$ I have in mind a different contrast between these terms than, say Ross (2002). Gellman (1992) also somewhat contrasts puzzlement and problematicity in a different way that I do here. 
contemporary discussion of the problem of evil but little discussed in the meantime. Rowe calls it the 'Moore shift.'

Because my thoughts on this subject stem from thoughts on the epistemological puzzle of skepticism, I will briefly discuss it. To that end, consider the following argument.

\section{Skeptical Argument 1}

Our evidence supports our ordinary beliefs only if our evidence discriminates between ${ }^{3}$ the contents of those beliefs and skeptical hypotheses.

(1) Our evidence does not discriminate between the contents of our ordinary beliefs and skeptical hypotheses.

(2) Therefore, our evidence does not support our ordinary beliefs.

This is a very plausible argument. It is a valid argument with two very plausible premises. Premise 1 seems true by definition. On behalf of Premise 2 are presented cases that indicate that our evidence is exactly what it would be in skeptical scenarios. ${ }^{4}$ Things would look exactly the same to us if we were brains in vats or the victims of malevolent daemons. Some are driven to desperate measures and embrace externalisms. Disjunctivists adopt radical notions of evidence that sever its natural ties to experience. Reliabilists essentially change the subject, giving us a theory of epistemic justification that makes it utterly puzzling how anyone could ever have worried about skepticism in the first place (See Conee and Feldman 2004). But there are skeptical arguments that successfully sidestep the issue, such as the following.

\section{Skeptical Argument 2}

(1) We have no right to affirm our beliefs if our experience would be exactly the same according to alternative hypotheses.

(2) Our experience would be exactly the same according to a number of alternative hypotheses.

\footnotetext{
${ }^{2}$ Rowe introduces the term in Rowe (1979). Perry (1999) and Geivett (1993) make prominent use of a Moore-shift-style argument, but few others have.

${ }^{3}$ By "discriminates between" I mean, essentially, favors one over the other.

${ }^{4}$ The basic notion of evidence here is that which is what we have to go on in forming beliefs. Obviously, from the first-person perspective, this consists in our experiences. See Dougherty and Rysiew (2013) for a defense of this view.
} 
(3) Therefore, we have no right to affirm our beliefs.

It is not at all easy to say where this argument goes wrong, and there is a massive, highly-disputed literature on how best to respond to it. But what's really interesting is that there are almost no epistemological skeptics whose skepticism matches the scope of these arguments. Think about that for a second: here we have a clearly valid argument, with one definitional premise, one extremely plausible premise, and no generally accepted understanding of where the argument goes wrong, but almost no one accepts the conclusion. That's a bit odd in a way.

I propose that the explanation of this rather remarkable fact is that we are almost all of us good Mooreans, even those of us who don't advocate Moore's response to the argument (which I think of as puzzle, not a problem, but more of that in a bit). Thus we are untroubled by the argument because we confidently and rightly believe the conclusion false. However, we are puzzled by it, because there is no obvious place where it goes wrong. The essence of Moore's response to the skeptical argument was that he was more convinced of the negation of the conclusion than the conjunction of any philosophy stuff in the premises, however initially plausible sounding. The argument was not a problem for Moore, and it is not a problem for Mooreans (whether implicit or explicit) (see Kelly 2008). It is, rather, a mere puzzle.

So in rough terms - this is not meant to be an exceptionless generalization or a conceptual analysis - an argument is a problem for someone when it is a plausible argument for a troubling conclusion troubling to that person - and that person is not already in fairly easy possession of warrant for the negation of the conclusion. If one is in fairly easy possession of warrant for the negation of the conclusion, then it is a mere puzzle. ${ }^{5}$ I will now apply this distinction to arguments for atheism from evil and from divine hiddenness.

\section{THE PROBLEM OF EVIL}

In this section, I will present two kinds of (potential) problems of evil. One depends on an argument in the way the other does not.

${ }^{5}$ Someone might, though, simply lack an inquisitive character and not be easily puzzled. 


\section{The Evidential (Potential) Problem of Evil}

Let an omniGod be a nonphysical substance ${ }^{6}$ with intentional power having no limits save logic alone. That is, roughly, a being who can know everything it is logically possible for that being to know and do everything logically possible for that being to do (with the caveat that no possible being could have more intentional power than that being). For short, we will say that being is omniscient and omnipotent. Given a plausible form of motivational internalism about goodness, omniscience and omnipotence logically entail perfect goodness or omnibenevolence. For an omniscient God would know the value of every possible state of affairs. And according to a form of motivational internalism that we might trace to Socrates, agents are motivated to pursue something in proportion to their perceived goodness unless they suffer weakness of will. But, being omnipotent, God will never suffer any weakness of will. The Judeo-Christian and Islamic conceptions of God go much further than this, of course, but classical forms entail at least this much, so any argument against an omniGod prima facie counts as arguments against the Abrahamic God.?

Having very briefly described the target and its relation to religious belief, here is an argument that could be a problem for theists.

\section{The Argument from Unjustified Bad States of Affairs (evils)}

(1) If there were an omniGod, there would be no unjustified evils.

(2) There are unjustified evils.

(3) Therefore, there is no omniGod.

A few brief comments are in order. Note that the first premise is (theo) logical in nature. Given the background theology, it is a logical truth.

${ }^{6}$ All I mean to convey by ascribing substancehood is an actually existing entity with causal powers that exists in and of itself, as apposed to, say, a quality or property inhering in something else. It is a form of independence in existence. One could further go on and ascribe a more robust form of independence to God, aseity or self-existence. I am all for this but won't be discussing it here.

${ }^{7}$ I will bracket a discussion of whether the Judeo-Christian God is an omniGod. All that really matters here, for my thesis, is that the JC-God has more attributes than but at least the attributes of the "God of the philosophers." Because of this, an argument that there is no being having the properties of the God of the philosophers is an argument that there is no JC-God. OmniGodhood here can stand in for whatever extra goodmaking properties you think the God of Abraham, Isaac, and Jacob has over and above the God of the philosophers. 
The antecedent entails the consequent. The second premise is an empirical claim. It's a claim about what one can, contingently, find in the actual world. This empirical claim is not obvious, unlike the mere claim that there is some evil in the world (the premise minus the term "unjustified") and unlike the first premise (given the background theology). Thus this premise requires evidence, and it is known in advance that this premise cannot be known with certainty but, rather, can only be assigned some probability on total evidence.

Some have thus called this form of the argument the 'evidential' argument from evil (See Howard-Snyder 1996: xi-xx). But there is no sensible contrast with a 'logical' problem of evil. For in this argument, the first premise states an obvious logical incompatibility and the second premise makes a non-obvious claim in need of evidential support. But in the version of the argument where we subtract the word "unjustified" we get the opposite result: the second principle makes a claim no sensible person could deny but the first premise becomes highly questionable and in need of evidential support. Thus the old contrast between an 'evidential' and 'logical' problem of evil isn't really doing any interesting work. This is the only gloss on this argument I will make in this essay.

Thus the argument from evil. But for whom might this argument be a problem? It is not a problem for atheists, clearly enough. The most plausible class of people for whom it might be a problem is theists who have some reason to believe the second premise. But it will all depend on how they come by their justification for being a theist in the first place and the balance between the strength of their reasons for being a theist and the strength of their reasons for believing the second premise. Rowe's Moorean shift is precisely the 'move' whereby one's direct warrant for theism swamps the warrant for belief in unjustified evil. For such theists this argument is not a problem, but merely a puzzle (and of course it is a matter of degree, people potentially lying upon a broad spectrum of problematicity and puzzlement). But if one is not in a position to pull off a Moorean shift, one has a problem indeed.

\section{Existential Problem}

The literature on the problem of evil contains another problem of evil, often called the 'existential' problem of evil. For the religious believer there is an existential problem of evil sensibly called the "pastoral" problem of evil. Alvin Plantinga puts it this way: 
Faced with the shocking concreteness of a particularly appalling example of it in his own life or the life of someone close to him, a believer may find himself tempted to take towards God an attitude he himself deplores; such evil can incline him to mistrust God, to be angry with him, to adopt towards him an attitude of suspicion and distrust, or bitterness and rebellion. This is a pastoral, or religious, or existential problem of evil (Plantinga 1992: 39).

But then there is an existential problem that is a bit different. No one puts it better than Yehuda Gellman.

The problem of evil that philosophers deal with is an intellectualized construction upon a basic human experience of God's non-existence. For I want to argue that just as there is a human experience of God's existence, there is likewise and just as surely a human experience of God's non-existence. And the latter is to be found in humanity's experience of evil. (Gellman 1992: 211-12)

As a result, says Gellman, 'The experience of evil provides prima-facie justification for God's non-existence' (Gellman 1992: 214). In this experience, God, we might say, 'seems absent.' There is no inference, no argument that moves from facts about evil to alleged facts about God. Rather, there is simply an experience of evil such that in that experience, God seems absent. We will come back to this in some detail shortly. First, however, I want to present a parallel contrast in the argument from divine hiddenness.

\section{THE PROBLEM OF DIVINE HIDDENNESS}

Just as there is an evidential (potential) problem of evil stemming from a discursive argument and an existential problem of evil stemming from an experience, so there is an evidential (potential) problem of divine hiddenness stemming from a discursive argument and an existential problem of divine hiddenness stemming from an experience.

\section{Epistemic problem}

The simplest form of the argument from divine hiddenness goes like this:

If there were an omniGod, there would be no non-culpable disbelief.

(1) But there is some non-culpable disbelief.

(2) Therefore there is no omniGod. 
Similar to our argument from evil, the first premise of the argument from hiddenness is supposed to be a theological truism (though it has been questioned extensively $y^{8}$ ). And the second premise is an empirical claim. It is very plausible and might seem obvious at first until one starts to think about what basis they have for making such a judgment. Though I don't think this is a very strong argument, I do think divine hiddenness can present a serious problem, as we shall see shortly. First, though, we will look at another version of the problem.

\section{Existential problem}

The existential problem of divine hiddenness is encountered when one either lacks any sense of God's presence or senses his absence. The notion of sensing an absence is somewhat obscure and contentious but, I think, helpful. I don't insist that it isn't reducible to more basic notions, but I do think the phenomenology is substantively different. It could be, for example, that sensing absence is a function of expectation. ${ }^{9}$ If one expected to see something in a room - not consciously, but by habit - it's absence could grab their attention. Many readers will have experienced that "Something has moved, hasn't it?" moments. For now, I'll ask the reader's charity.

The epistemic problem is one of belief and evidence alone. Though belief and evidence are implicated in the existential problem of hiddenness, the problem goes beyond that. For evidence can be indirect. In the existential version, there is a directness at the heart of the problem. It's not just that God is missing from the list of things one has sufficient evidence for. I have sufficient evidence for the existence of my wife, but she's not currently present, and is a kind of absence-from-my-experience that has features not had by evidential-absence-from-my-justifiedontology. Here is a classic example from Saint Mother Theresa.

God, who am I that You should forsake me? The child of your love - and now become as the most hated one - the one You have thrown away as unwanted- unloved. I call, I cling, I want - and there is no One to answer no One on Whom I can cling - no, No One. - Alone. The darkness is so dark...The loneliness of the heart that wants love is unbearable. - Where is my faith? - even deep down, right in, there is nothing but emptiness \&

${ }^{8}$ See the classic collection, Howard-Snyder and Moser (2002), and Poston and Dougherty (2007).

9 Thanks to Brandon Rickabaugh for this suggestion. 
darkness. - My God - how painful is this unknown pain. It pains without ceasing... I am told God loves me - and yet the reality of darkness \& coldness \& emptiness is so great that nothing touches my soul... What are You doing My God to one so small? (Mother Teresa 2007: 186-87)

Now there is a kind of paradox here illustrated by the following little verse.

The other day upon the stair

I met a man who wasn't there.

He wasn't there again today.

Oh how I wish he'd go away.

It also reminds of the definition of the "New atheist" as someone who is very angry at God for not existing. For the words in a way suggest both belief that God exists and assertions of his absence. In the case of St. Mother Theresa, I think it is clear she believes that God is real, not make believe, but that she is being denied the vision of him she once had. This would be analogous to my lamenting that my wife will not come home to see me, and is instead choosing to remain at a great distance. This feeling is captured well by the psalmist:

Why do You stand afar off, O LORD? Why do You hide Yourself in times of trouble? (Psalm 10:1)

At times the experience is event that God is deftly dodging out of sight at every turn.

Behold, I go forward, but he is not there, and backward, but I do not perceive him; on the left hand when he is working, I do not behold him; he turns to the right hand, but I do not see him. (Job 23:8-9)

In this kind of existential hiddenness, the subject is not asserting that God is not among the things there are, not asserting that God is missing from the list of existing things, non-imaginary things.

\section{THE PROBLEM OF EVIL AND THE PROBLEM OF HIDDENNESS}

I now wish to talk about the relationship between these two pairs of possible sources of trouble for traditional theists. First, note that it is not easy to distinguish the existential problem of evil and the existential problem of hiddenness. Both are characterized by the encountering of an experience which seems to reveal God's absence in the world. In the experience of certain horrific evils, we might say, God is hidden 
in evil. It may be that they are in fact the same problem under two guises. Or it may be that careful analysis can show that they are not identical problems but rather only importantly overlap. I leave that as homework.

The main burden of this final section of this essay is to pick up Gellman's thread and spin it into a fabric of some extent. First, though, I wish to make a few observations about the logical relation between the two arguments.

First, suppose existential hiddenness did not occur. That is, suppose you had a strong sense of God's abiding presence. Then you would have enough conviction in the falsity of the conclusion of the argument from evil that the argument would constitute a puzzle, not a problem. You could do a Moorean shift. So in this sense, the problem of evil depends upon the problem of hiddenness. In the terms of attachment theory, our sense of wellbeing in the presence of evil depends on having a secure attachment to God, in virtue of previous events of sensing God's presence. ${ }^{10}$

More specifically, note that "S suffers" (in a way that seems to S to lack justification) is logically equivalent to the following disjunction of conjunctions:

((S suffers \& S feels God's assuring presence) v (S suffers \& S does NOT feel God's assuring presence))

The first disjunct is going to have trouble generating a problem for S. For its second conjunct is going to (at least tend to) provide a defeater for $\mathrm{S}$ for the problem its first conjunct is supposed to get her into. That is, it enables a Moorean shift, which lands us in a puzzle, not a problem.

But the second disjunct is a conjunction of the basis for the empirical premise of the argument from evil and the basis of the existential problem of hiddenness. So it appears that S's sense of seemingly pointless suffering doesn't do any work all by itself. It needs to be conjoined with that $S$ does NOT feel God's assuring presence. Since that second conjunction is also not by itself a very strong basis for an inductive argument for atheism from evil, it appears that the only way to generate a real problem of evil is by combining the empirical premise and the hiddenness premise. In addition to these logical relations there are also some deeper lessons to which I now turn.

${ }^{10}$ See Bowlby (1969) and Bretherton (1992). This was pointed out to me by Brandon Rickabaugh. 


\section{The common sense problem of evil}

Unjustified evil ${ }^{11}$ logically entails that there is no God. That is semantically equivalent to saying that every possible world with unjustified evil is one where God is absent. ${ }^{12}$ God and unjustified evil are non-compossible, they never occupy the same logical space. There is an analogous phenomenon in our emotional lives. Sometimes two things cannot coexist in our emotional world, they are emotionally non-compossible. The presence of one emotion in our life excludes another. For example, one cannot simultaneously stand in awe-admiration of something and also despise-and-deplore it. There are times when God and the holocaust are like this for me. My world can't contain them both. If one exists, the other doesn't (and the latter clearly isn't the candidate for denial). There are a number of recent news items that follow me around like hungry jackals, mocking my faith. I'm like a weak member of the herd, lagging behind, prime for being taken down.

It seems that experiencing horrendous evils ${ }^{13}$ is non-compossible with experiencing joy or perhaps hope. Therefore, I will use the nearby term "horrific evils" to refer (approximately) to those evils that have this emotionally exclusionary effect on one. ${ }^{14}$

So let ' $\mathrm{H}$ ' state that one of these horrific evils has occurred, and let ' $G$ ' state that God exists. An instance of the argument from evil from a particular horrific evil would say that $\mathrm{H}$ and $\mathrm{G}$ are noncompossible that $\mathrm{H}$ logically excludes $\mathrm{G}$ - and then conclude, by way of affirmation of $\mathrm{H}$ - that not $\mathrm{G}$. An argument from any particular horrific evil will be weak by the nature of the case: we know so little about the details of any case and noseeum inferences are no good. However, even though a particular argument from a particular horrific evil might be logically

${ }^{11}$ I'm using the broad, intuitive notion here: there needs to be a sufficient reason for God to permit any bad state of affairs. What counts as a sufficient reason will vary by user.

12 If God exists and God is a necessary being, then no possible world will have any unjustified evil. So a perfectly precise statement of the situation would need to have recourse to impossible worlds or perhaps some situation-theoretic model. The point, I take it, is perfectly clear, however.

13 The term 'horrendous evils' has acquired a technical sense in the work of Marilyn Adams (see Adams 2000 and 2006). Horrendous evils are those that when experienced cause us to wish we had not been born.

${ }^{14}$ To be clear, this is a relation- $\mathrm{x}$ is horrific to $\mathrm{y}$ at $\mathrm{t}$-not a monadic property of events or states of affairs. 
weak, it could nevertheless be emotionally very strong. ${ }^{15}$ That is, our emotional world may not be able to accommodate both $\mathrm{H}$ and $\mathrm{G}$. Thus, if $\mathrm{H}$ is quite salient to us, the possibility of $\mathrm{G}$ will seem quite remote.

\section{From emotions to reasons}

I am inclined to think normative reasons are motivating reasons for the usual reasons some people think that (Dancy 2000), though I realize this is controversial. I'm sanguine about the possibility of translating what I say below into alternative reasons-discourse. This thesis combined with my view of emotions - things that motivate - I am inclined to take reasons to be a species of emotion (and somewhat inclined to think that all emotions are reasons, though they need not always be good reasons). But I will not assume that here. Rather, I will only assume what I think is hardly contestable: that emotions can provide (in a number of ways) reasons. ${ }^{16}$

Much of our evidence (I am inclined to think most of it) consists in what is commonly described as 'taking' things to be a certain way. Either the same phenomenon by a different name or a similar phenomenon is sometimes described as 'seeing as.' When we take something to be the case or see something as having a certain characteristic, we might also say the world 'appears to us' to be a certain way. ${ }^{17}$ I call these takings or seeings as or appearances or even "seemings"18 as evidence because they clearly justify belief. ${ }^{19}$ If there is one position in all of philosophy to which I will never give any quarter, it is disjunctivism..$^{20}$ At any rate, it seems clear that emotions affect how we take the world to be, color how

15 Bruce Russell tends to argue from particular horrific evils. See, for example, Howard-Snyder (2002) and Pojman (2008). Tooley (2015) thinks this is the best way to run the argument. For reasons too lengthy to get into here, I think he is mistaken about that, but see Dougherty and Pruss (forthcoming).

16 On the relationship between emotions and reasons see Robert Roberts (1988, 2013), and Michael Brady (2013).

17 The "adverbial" theory of perception is but one way of precisifying this. See, for example, Chisholm (1977).

18 See Tucker (2013) for several takes on seemings.

19 The claim here is not that they are the only things that justify belief, but only that they are among the things that justify belief. See Huemer 2001, Swinburne 2001, Conee and Feldman 2004, and again, the Tucker volume.

20 Although, see Pritchard (2012) for an interesting, creative, and more sympathetic discussion of it. On any theory of justification for which blamelessness is insufficient (disjunctivists usually say that narrow mental content only excuses from blame for lack of justification), I am more interested in "blamelessness" than "justification." 
we see it, give it a certain character or appearance. Thus the emotions even if they don't constitute evidence (as I am inclined to think) - impart a certain character to our experience, thus determining to a considerable extent what we have reason to believe.

\section{THE COMMON SENSE PROBLEM OF EVIL}

This epistemological perspective forms the basis for seeing how the existential problem of evil can give rise to an evidential problem of evil. I have called a simplified version of Swinburne's formulation of the atheistic argument from evil (Swinburne 1998: 19-20) the 'common sense problem of evil' (Dougherty 2008, 2011, 2014a, 2014b, 2014c, Dougherty and Walls 2013). Swinburne's formulation is a masterful example of how to carefully craft a deductively valid argument taking every consideration into account. It is, however, much more complicated than a representative argument by any but the very most sophisticated and informed atheists. Nevertheless, the insight at its core is simple enough. Speaking of the inquiring atheist, Swinburne writes, 'It might seem to him that the horror is so great that under no circumstances would God have any right to let it occur' $(1998,28)^{21}$. Such horrors are described by Ivan Karamazov (Dostoyevsky 1880: 245-46), and they turn the stomach of any properly functioning human. Swinburne writes 'Many of us are surely often in this situation, and there would be something wrong with us morally if we were not' (1998: 29).

Importantly, for my present purposes, this perspective on the world isn't the result of ratiocination simple or complex..$^{22}$ It is a visceral reaction to reality. In the grips of such an experience we take there to be no God, we see the world as incompatible with God, the horror appears directly to be utterly unjustifiable by any possible greater good. ${ }^{23}$ These experiences are colored by our emotional constitution - as they ought to be - and as basic experiences give us reasons to believe their propositional contents,

${ }^{21}$ Swinburne also considers some other relevant possible basic starting points, but I find them each problematic in various ways, considerably more problematic than the impermissibility version. See also Plantinga 2000: 14, for a similar line of thought.

${ }^{22}$ Caroline Paddock pointed out to me that it is always Dostoyevsky's philosophers who are skeptics.

${ }^{23}$ These are not necessarily meant to be alternative descriptions of one and the same reality, but they may well be descriptions of various facets of one and the same reality. Alternatively, they may be relevantly similar situations or three theories of one observed reality. It's just hard to tell. 
unless we have reason to think they are misleading (that is, in this case, unless we have a theodicy).

One other epistemological ingredient in the present discussion is a principle that Swinburne has used in one way or another throughout his reflections in philosophy of religion, a principle he tends to call 'The Principle of Credulity' (1979, 1998, 2001, and 2004). One form he gives the principle is this.

\section{Principle of Credulity}

Other things being equal, it is probable and so rational to believe that things are as they seem to be (and the stronger the inclination, the more rational the belief) (1998: 26). ${ }^{24}$

I myself do not find the notion of full belief or of binary justification or rationality as a property of it helpful except when nothing much hangs on precision. One or two small but significant items may hinge on a bit greater precision here, so I will briefly canvass my alternative picture beginning with the following principle.

Reasons Commonsenseism ( $R C$ )

If it seems to $\mathrm{S}$ that $\mathrm{P}$ with strength $\mathrm{D}$, then $\mathrm{S}$ thereby has a pro tanto reason of strength $\mathrm{D}$ to believe $\mathrm{P}$.

I only want to make a few clarifications. First, in my terminology, there is a difference between its seeming that $P$ and it's seeming as though $P$. If it seems that $\mathrm{p}$, then if you are properly functioning you will be inclined to affirm P. If it merely seems as though $\mathrm{P}$, there is no such default. To illustrate, consider the lines in the Müller-Lyer illusion. Due to the optical illusion, they seem as though they were different lengths. But to anyone who knows about the illusion, there will be no temptation to believe that they are. The proposition that the lines are different lengths will get no epistemic 'oomph' from the seeming as though, in light of awareness of the illusion. In general, sensory experiences enable but do not constitute seemings. And I am using 'seemings' in this context as a catch all term for seeming that, takings, seemings as, and ways the world appears to be.

By a 'pro tanto reason' I only mean the fairly literally translated reason of "just so much" weight. Such reasons can range widely in strength and can always be outweighed by further evidence. Note that, similarly to

${ }^{24}$ Swinburne goes on to revise the principle in certain ways, but they need not concern us here. 
Swinburne's formulation of the Principle of Credulity, the epistemic strength is in proportion to the magnitude of the psychological property from which it arises. The guiding notion here is, again, that our evidence is what guides us in the formation of our attitudes towards representations of the world (and, of course, ideally guides the unconscious process of forming those representations). And in the end, we have nothing more than our own perspective to guide us, though I hasten to add that a crucial part of our perspective involves other people both in how they, often unbeknownst to us, influence our perspective (provided by our senses, memory, and other faculties) and how their testimony helps build our perspective. In the end, we can only see through our own eyes.

With these clarifications in mind, consider the following versions of the Common Sense Problem of Evil (CSPOE). I will formulate them with respect to some given horrific evil $\mathrm{E}$, which we will assume to has occurred, though as I point out above, that is not the only or necessarily the best way to do it. We might also be able to let ' $E$ ' name the largest complex amalgam of evils we are capable of attending to in one act of the mind. However, because I don't believe there is any such thing as a sum of all evil, I personally think of $\mathrm{E}$ as at most a disjunction of the claims about the suffering of particular individuals. For it is to individuals that God owes justice or, if, like me you follow Marilyn Adams, the real issue is that it is towards individuals that the God of Christian theism will show loving kindness in all things.

\section{CSPOE Schema}

(1) It strongly seems to $S$ that E's occurring is absolutely incompatible with an omni-God's existence.

(2) Therefore, by RC, S has a strong reason to think there is no omni-God.

The important thing here is that this is not an inference $\mathrm{S}$ makes. It is an inference we make about S in light of RC. Given RC and S's take on the world, she just thereby has a strong reason to doubt that there is a omni-God. There is no so-called 'noseeum' inference (See Wykstra 1984), and she needn't have ever heard of skeptical theism or it's skeptical theses (Bergmann 2009), much less be convinced by it. ${ }^{25}$ Standard skeptical theism, which is supposed to prevent you from ever getting

\footnotetext{
${ }^{25}$ And note that the common sense problem of evil remains even if the skeptical theist insists that she must be improperly functioning.
} 
non-inferential reasons for theism, appears to be inconsistent with RC. ${ }^{26}$ So much the worse for skeptical theism. Alvin Plantinga captures the thought well. After cataloguing some particularly horrific evils, he says

wouldn't a rational person think, in the face of this kind of appalling evil, that there just couldn't be an omnipotent, omniscient, and wholly good person superintending our world? Perhaps he can't give a demonstration that no perfect person could permit these things; perhaps there isn't a good probabilistic or evidential atheological argument either: but so what? Isn't it just apparent, just evident that a being living up to God's reputation couldn't permit things like that? Don't I have a defeater here, even if there is no good antitheistic argument from evil? (Plantinga 2000: 484).

The schema for the problem isn't, as such, a problem for anyone. It all depends upon the value of the variable 'S'. As Swinburne says, we are often in this position, so a particularly salient version of the problem is the first-personal version.

\section{CSPOE First Person}

(1) It strongly seems to me that E's occurring is absolutely incompatible with a omni-God's existence.

(2) Therefore, by RC, I have a strong reason to think there is no omni-God.

\footnotetext{
${ }^{26}$ At least according to the application of skeptical theist. For example, Bergmann argues, "Thus, Swinburne misconstrues the skeptical theist's response. He thinks the skeptical theist's aim is to show that the likelihood of some evil or other on theism might for all we know be higher than it initially appears. And he replies that similar remarks show that it might for all we know be lower than it initially appears. Since, according to him, it's just as likely to be higher than it initially appears as it is to be lower than it initially appears, it's reasonable to go with initial appearances. But in fact, the skeptical theist's response is that we aren't justified in thinking the probability judgment initially appears the way Swinburne says it appears. Clear thinking and reflection on ST1-ST4 reveal that there's no particular value or range (short of the range between 0 and 1) that the probability in question appears to be (Bergman 2009: 387)." The inconsistency is not entailed merely by the skeptical theists skeptical theses. Wykstra (1984), the font of skeptical theism, obtains his original but now often-modified CORNEA principle via additions to Swinburne's Principle of Credulity. He now explicitly defends a probabilistic understanding of CORNEA. See Wykstra (2007) and his 'Skeptical Theism, Abductive Atheology, and Theory Versioning' in Dougherty (2014). But he still defends it with a parent analogy, which is criticized in Dougherty (2012).
} 
If one is a theist, then the problem may (and perhaps should!) start at home. This is not to suggest for a moment that the reason outweighs all other reasons or isn't undercut somehow or that it remains constant. It is perfectly consistent for a theist to remain a theist in good cognitive standing and still have this problem. For example, the theist may have an undercutting defeater in a Theodicy or a rebutting defeater in natural theology, or both. These qualifications are consistent with the first-person problem being a big problem. ${ }^{27}$

However, even if we work through our personal intellectual difficulties and their social and experiential foundations, we all care about other people. And sometimes, other people we care about struggle with difficulties in belief. Thus, the third-personal version of the common sense problem of evil is salient.

\section{CSPOE Third Person}

(1) It strongly seems to Dolores that E's occurring is absolutely incompatible with a omni-God's existence.

(2) Therefore, by RC, Dolores has a strong reason to think there is no onmi-God.

If Dolores is your friend, and she is a theist, she has a problem. And the problem, though emotional in origin, has become an evidential problem because of the reasons-generating power of emotions. And in a kind of emotional feedback loop, Dolores might suffer emotionally from confronting this evidential problem.

And if you are a theist and you are in dialogue with someone concerning belief, you may have to face this issue yourself. Then it becomes a second-personal problem. You must read this version as though you were speaking it to your good friend Dolores.

\section{CSPOE Second Person}

(1) It strongly seems to you that E's occurring is absolutely incompatible with a omni-God's existence.

(2) Therefore, by RC, you have a strong reason to think there is no onmi-God.

If you are a religious person yourself, then you will, if you are compassionate, want others to share in the blessings of belief. So you will

\footnotetext{
${ }^{27}$ I have little if anything to say to fideists for whom having a strong reason to think there is no God is literally not a problem worth taking seriously.
} 
want to address this problem with your friend. Skeptical theism is mute in this case. Many are helped by natural theology or theodicy (I know I am), but as this evidential problem has emotional sources, one can also try to point out the beautiful things in the world and usher them into a loving religious community and introduce them to powerful religious literature (Tolkien has done more for me on the problem of evil than about anyone) (See Stump, (2010), and Dougherty (2014c)).

Some people have personal proclivities toward one or another of these forms for addressing the common sense problem of evil. Some scientifically - or logically - minded people will feel more equipped to pursue the route of natural theology and be more satisfied by it (see Rickabaugh and McAllister (forthcoming) and Dougherty and Rickbaugh (forthcoming)). Some more literarily-minded people will prefer other rounds. Some (like me) will find them all attractive and be variably satisfied by versions of all of them.

Many of us will face all three versions of the common sense problem of evil. Hopefully, the religious path and the path of intellectual integrity will coincide, and, hopefully, as we walk this path it will help religious theists minister to those with whom we are in dialogue, regardless of where they are on the theism spectrum. The bottom line is that skeptical theism, in any of its standard forms, has nothing to say to the common sense problem of evil. Rather, what we need is a return to theodicy, natural theology, and proclamation of the goodness of the world, whether in history or fiction.

\section{CONCLUSION}

So it looks like the problem of evil is either indistinguishable from the problem of divine hiddenness (at the existential level) or, at the argumentative level, cannot make the leap from puzzle to problem unless hiddenness is already a problem. Yet perhaps the most common vehicle for existential hiddenness is existential evil, that is, the having of an experience that emotionally and imaginatively excludes God. It appears, then, that, in the standard case, at least, the two arguments are intimately bound together, and that most of the weight of the problem of evil rests on existential hiddenness. 


\section{BIBLIOGRAPHY}

Adams, Marilyn. (2000). Horrendous Evils and the Goodness of God. Ithaca, NY: Cornell University Press.

Adams, Marilyn. (2006). Christ and Horrors. UK: Cambridge University Press. Bergmann, Michael. (2009). 'Skeptical Theism and the Problem of Evil', in T.

Flint and M. Rea (eds.), Oxford Handbook of Philosophical Theology. Oxford: Oxford University Press.

Bowlby, John. (1969). Attachment and Loss. 3 Vol. New York: Basic Books.

Brady, Michael S. (2013). Emotional Insight: The Epistemic Role of Emotional Experience. Oxford: Oxford University Press.

Bretherton, Inge. (1992). 'The Origins of Attachment Theory: John Bowlby and Mary Ainsworth.' Developmental Psychology 28: 759-775.

Chisholm, Roderick. (1977). Theory of Knowledge, 2d edition. Englewood Cliffs: Prentice-Hall.

Conee, Earl. and Richard Feldman. (2004). 'Making Sense of Skepticism', in E.

Conee and R. Feldman (eds.), Evidentialism. Oxford: Clarendon Press.

Dancy, Jonathan. (2000). Practical Reality. New York: Oxford University Press.

Dougherty, Trent. (2008). 'Epistemological Considerations Concerning Skeptical Theism', Faith and Philosophy 25 (2): 172-76.

Dougherty, Trent. (2011). 'Further Epistemological Considerations Concerning Skeptical Theis.', Faith and Philosophy 28 (3): 332-40.

Dougherty, Trent. (2012). 'Reconsidering the Parent Analogy: Unfinished Business for Skeptical Theists', International Journal for Philosophy of Religion 72 (1): 17-25.

Dougherty, Trent. (2014a). 'Phenomenal Conservatism, Skeptical Theism, and Probabilistic Reasoning, T. Dougherty and J. P. McBrayer (eds), Skeptical Theism: New Essays. Oxford University Press.

Dougherty, Trent. (2014b). 'Skeptical Theism', Stanford Encyclopedia of Philosophy. http://plato.stanford.edu/archives/spr2014/entries/skepticaltheism/.

Dougherty, Trent. (2014c). The Problem of Animal Pain: A Theodicy For All Creatures Great And Small. (New York: Palgrave Macmillan).

Dougherty, Trent and Alexander R. Pruss (forthcoming). "Evil and the Problem of Anomaly." Oxford Studies in Philosophy of Religion. Oxford: Oxford University Press.

Dougherty, Trent and Brandon Rickabaugh. (forthcoming). "Natural Theology, Evidence, and Epistemic Humility." European Journal for Philosophy of Religion.

Dougherty, Trent. and P. Rysiew. (2013). 'What is Knowledge-first Epistemology?' 'Experience First,' and 'Still Nowhere Else to Start', in M. Steup, J. Turri, E. Sossa (eds), Contemporary Debates in Epistemology, 2nd edition. Oxford: Wiley-Blackwell. 
Dougherty, Trent and Jerry L. Walls. (2013). 'Arguments from Evil.' In The Routledge Companion to Theism', edited by C. Taliaferro, V. Harrison, and S. Goetz. New York: Routledge, 369-82.

Dostoyevsky, F. (1880). The Brothers Karamazov, tr. Constance Garnett, 1933. New York: Random House.

Gellman, J.I. (1992). 'A New Look at the Problem of Evil', Faith and Philosophy 9(2): 210-216.

Geivett, Douglas R. (1993). Evil \& the Evidence for God: The Challenge of John Hick's Theodicy. Philadelphia, PA: Temple University Press.

Howard-Snyder, Daniel. (ed). (1996). The Evidential Argument from Evil. Indianapolis: Indiana University Press.

Howard-Snyder, Daniel and Paul Moser. (2001). Divine Hiddenness: New Essays, Cambridge. UK: Cambridge University Press.

Huemer, Michael. (2001). Skepticism and the Veil of Perception. Rowman \& Littlefield.

Kelly, Thomas. (2008). 'Common Sense as Evidence: Against Revisionary Ontology and Skepticism.' Midwest Studies in Philosophy 32: 53-78

Mother Teresa (2007). Come Be My Light: The Private Writings of the Saint of Calcutta, edited with commentary by Brian Kolodiejchuk. New York: Doubleday.

Perry, J. (1999). Dialogue on Good, Evil, and the Existence of God. Cambridge, MA: Hackett Publishing.

Plantinga, Alvin. (1992). 'Epistemic Probability and Evil', in K. Clark (ed.), Our Knowledge of God. Norwell, MA: Kluwer Academic Publishers.

Plantinga, Alvin. (2000). Warranted Christian Belief. Oxford: Oxford University Press.

Pojman, Louis and Michael Rea. (2008). Philosophy of Religion: An Anthology. Stamford, CT: Cengage Learning.

Poston, Ted and Trent Dougherty. (2007). 'Divine Hiddenness and the Nature of Belief,' Religious Studies 43: 183-98.

Pritchard, Duncan. (2012). Epistemological Disjunctivism. Oxford: Oxford University Press.

Rickabaugh, Brandon, and Derek McAllister. (forthcoming). 'Who You Could Have Known: Divine Hiddenness, Epistemic Counterfactuals, and the Recalcitrant Nature of Natural Theology', International Journal for Philosophy of Religion, (forthcoming). DOI: 10.1007/s11153-016-9580-3

Roberts, Robert C. (1988). 'What an Emotion Is: A Sketch.' Philosophical Review 97:183-209.

Roberts, Robert C. (2013). Emotions in the Moral Life. Cambridge: Cambridge University Press.

Ross, J.J. (2002). 'The Hiddenness of God: A Puzzle or a Real Problem?', in D. Howard-Snyder and P. Moser (eds.). Divine Hiddenness: New Essays. Cambridge, UK: Cambridge University Press. 
Rowe, William. (1979). 'The Problem of Evil and Some Varieties of Atheism', American Philosophical Quarterly 16: 335-41.

Stump, Eleonore. (2010). Wandering in Darkness: Narrative and the Problem of Suffering. Oxford: Oxford University Press.

Swinburne, Richard. (1979). The Existence of God, 1st Edition. Oxford: Oxford University Press.

Swinburne, Richard. (1998). Providence and the Problem of Evil. Oxford: Oxford University Press.

Swinburne, Richard. (2001). Epistemic Justification. Oxford: Oxford University Press.

Swinburne, Richard. (2004). The Existence of God, 2nd Edition. Oxford: Oxford University Press.

Tooley, Michael. (2015). 'The Problem of Evil.' In Edward N. Zalta (ed.), The Stanford Encyclopedia of Philosophy. URL = <http://plato.stanford.edu/ archives/fall2015/entries/evil/>.

Tucker, Chris. (2013). Seemings and Justification: New Essays on Dogmatism and Phenomenal Conservatism. Oxford: Oxford University Press.

Wykstra, Stephen. (1984). 'The Humean Obstacle to Evidential Arguments from Suffering: On Avoiding the Evils of 'Appearance", International Journal for Philosophy of Religion 16(2): 73-93.

Wykstra, Stephen. (2007). 'CORNEA, Carnap, and Current Closure Befuddlement', Faith and Philosophy 24(1): 87-98.

Wykstra, Stephen. (2014). 'Skeptical Theism, Abductive Atheology, and Theory Versioning, in T. Dougherty and J. McBrayer (eds.). Skeptical Theism: New Essays. Oxford: Oxford University Press. 